Contents available at: Sri Lanka Journals Online

\title{
Evaluation of Tea Smallholder's Attitudes on Recommended Agricultural Practices in Tea: A Case Study in Pussellawa Tea Extension Officer Range, Sri Lanka
}

\author{
C.E. Munasinghe ${ }^{1 *}$, U. Dissanayeke ${ }^{2}$ and W.A.D.P. Wanigasundera ${ }^{3}$ \\ ${ }^{1}$ Tea Research Institute, Talawakelle, Sri Lanka. \\ ${ }^{2}$ Department of Agricultural Extension, Faculty of Agriculture, University of Peradeniya, Peradeniya, Sri Lanka. \\ ${ }^{3}$ Postgraduate Institute of Agriculture, University of Peradeniya, Peradeniya, Sri Lanka.
}

\section{ARTICLE INFO}

Article history:

Received: 15 August 2019

Accepted: 08 November 2019

Revised version received: 21 June 2020

Available online: 1 October 2020

Keywords:

Attitudes

Extension

Level of adoption

Recommended agricultural practices

Tea smallholders

\section{Citation:}

Munasinghe, C.E., Dissanayeke, U. and Wanigasundera, W.A.D.P. (2020).

Evaluation of Tea Smallholder's Attitudes on Recommended Agricultural Practices in Tea: A Case Study in Pussellawa Tea Extension Officer Range, Sri Lanka, Tropical Agricultural Research, 31(4): 3342

DOI: http://doi.org/10.4038/tar.v31i4.8419

Munasinghe, C.E.. (iD)

https://orcid.org/0000-0002-0380-6320

\section{ABSTRACT}

Tea smallholdings sector plays a major role in the tea industry of Sri Lanka contributing $75 \%$ to the national tea production. Attitudes of tea smallholders critically affect the adoption of recommended agricultural practices. This study was aimed at evaluating the attitudes of tea smallholders on the recommended agricultural practices in tea and the determinants responsible for shaping these attitudes. A sample of 110 smallholders was selected and primary data were collected using questionnaires. Multiple Regression and non-parametric statistical methods were adopted to analyse data using SPSS software package. In conclusion, a majority of tea smallholders had favourable attitudes on the recommended agricultural practices. With regard to the attitude determinants, farmer knowledge, experience and exposure to tea related extension programs have significantly affected in shaping the attitudes of tea smallholders. Farmer knowledge and experience showed a linear relationship with the attitudes of smallholders.

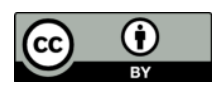

*Corresponding author : chanushka44@gmail.com 


\section{INTRODUCTION}

Tea (Camellia sinensis L. (0.) Kuntze) plays an important role in the socio - economic arena of Sri Lanka. Currently, 94 percent of the national tea production is exported contributing to 15 percent of the foreign exchange earnings of the country. Tea contributes $0.7 \%$ of the Gross Domestic Product (GDP) of Sri Lanka. Tea industry mainly consists of two sectors, namely the Estate Sector and Smallholdings Sector, occupying nearly 201,000 hectares in the country (Central Bank, 2017).

Tea lands below 4 ha (10 acres) in extent are defined as smallholding lands in Sri Lanka. The tea smallholdings sector is considered the most dynamic segment of the tea sector as it contributes $75 \%$ of the national production and $59 \%$ of total tea extent of Sri Lanka (TSHDA, 2012; Central Bank, 2017). The productivity of tea smallholdings sector remains around 2,100 Made Tea $\mathrm{kg} /$ ha (TSHDA, 2016) which is far below the potential level. Such low productivity of the smallholdings sector can mainly be attributed to many factors such as land degradation, aging of tea bushes, poor rate of replanting, pest and disease damages and poor adoption of recommended agricultural measures (Mahaliyanarachchi et al., 1996; Rajasinghe, 1999).

Despite the great potential of agricultural recommendations and innovations, the uptake of such technologies by smallholders seems to be slow. Mahaliyanarachchi et al. (1996) found out that only $32.5 \%$ of Low Country tea smallholders had a satisfactory knowledge on fertilizer usage and only $13.25 \%$ had a fair knowledge on pest management. Furthermore, surveying tea smallholders in Matara district, Samaraweera et al. (2013) found that only $20 \%$ had a good knowledge about overall tea cultivation. Several studies have been carried out all over the world to find out the factors affecting the level of adoption of smallholding farmers. Meijer et al. (2015) reviewed that uptake of agricultural innovations by the smallholding farmers largely depends on intrinsic factors such as knowledge, perceptions and attitudes of the potential adopter. In another study, Shikuku et al. (2017) assessed the influence of small scale farmer attitudes towards the adoption of recommended practices to avoid possible risks of climate change and showed that farmers' attitudes strongly favoured introduction of new crops, changes in crop varieties and planting times in adapting to climate risks.

Attitudes are defined as relatively enduring organization of beliefs, feelings and behavioural tendencies towards socially significant objects, groups, events or symbols. Attitudes are positive or negative evaluations or feelings that people have towards other people, objects, issues or events. Attitudes are formed by what is perceived to be true about the attitude-object and is manifested through practice by changing the behaviour of a person or organization (Vaughan and Hogg, 1995). In agriculture, farmer attitudes act as a crucial determinant of farmer behaviour and the positive attitudes affect intentions towards sustainable behaviour (Menozzi et al., 2015). Farmer attitudes play a significant role in farmer decision making for change particularly in adopting innovative technologies, novel concepts and sustainable agricultural practices. O'Shea et al. (2018) mentioned that the attitude of farmers is one important aspect influencing the decision making in mitigating emission of greenhouse gases in agriculture. Simultaneously, the negative attitudes of farmers' act as a deterrent factor for adoption and hence the attention needs to be paid to ensure generation of positive attitudes of farmers prior to introducing new technologies (Kulshreshtha et al., 1993).

Researchers and extension specialists of Sri Lanka have identified farmer attitudes as a key factor affecting the success of adopting innovative technologies and novel concepts in the smallholdings sector. Malkanthi et al. (2001) assessed attitudes of Up Country vegetable farmers on privatization of agricultural extension service. In another study, Mahaliyanarachchi et al. (2006) measured farmer attitudes on commercialization of agricultural extension by using an attitude measuring scale. Yapa et al. (2013) highlighted the negative attitudes 
of tea smallholders of Galle district towards implementing a fee-based extension service.

Considering the tea smallholdings sector of Sri Lanka, a less relative effort has been made to evaluate smallholder attitudes and the key attitude shaping determinants. This study was therefore aimed at evaluating the existing smallholder attitudes on sustainability of the tea industry and appraising key possible determinants responsible for shaping these attitudes. In the long run, it could be of use in selecting appropriate extension approaches in order to improve the attitude level of smallholders, thereby ensuring a better rate of adoption of innovative technologies in the smallholdings sector.

This study was conducted with the objectives of assessing the attitudes of tea smallholders with respect to some selected agricultural practices in tea that are recommended by the Tea Research Institute (TRI) of Sri Lanka, and identifying the possible factors for shaping these attitudes.

\section{MATERIALS AND METHODS}

Pussellawa Tea Extension Officer (TE0) range of Kandy district, Sri Lanka, was selected as the study area. One thousand one hundred tea smallholders coming under 12 smallholding societies in the Pussellawa TEO range were considered as the sampling frame of this study.

Using the member lists of each society, a sample of 110 tea small holders was selected based on Simple Random Sampling method. The sampling population comprised $1 \%$ of the sampling frame.

Two questionnaires were developed for data collection of smallholders (i.e. knowledge and attitudes) in simplified language. One questionnaire was prepared to collect essential basic information and measure knowledge of smallholders. This questionnaire included twenty (20) semi structured simple questions covering four major subject areas of tea cultivation allocating five questions for each subject (Plucking, Pruning, Pest and Disease management and Soil fertility management).

The second questionnaire consisted of attitude measuring questions, which consisted of fifteen (15) statements prepared based on the guidelines given by Likert (1932), Spector (1992), and Saravanan and Gowda (1999). These statements included three (03) major dimensions that lead to the sustainability of the tea industry, i.e. (i) economic viability, (ii) agronomic worthiness of recommended agricultural measures, and (iii) extension/ institutional support. Each statement was evaluated on a 5-point Likert Scale with weightage of $5,4,3,2$ and 1 for positive statements and the reverse scoring system for the negative statements.

Questionnaires were then subjected to a relevance test with a panel of subject specialists for further improvements. The reliability of questionnaires was performed using the Cronbach $\alpha$ as the reliability coefficient of the questionnaires as explained by Santos (1999). A group of respondents consisting of 12 tea smallholders was randomly selected outside the sampling population while representing the study area as explained by Kathuri and Pals (1993) to perform the reliability of questionnaire. The spilt-half analysis technique was adopted according to Cronbach's formula;

$$
\alpha=\left(N^{*} r / 1+(N-1)^{*} r\right)
$$

(Where $\mathrm{N}=$ number of items and ' $\mathrm{r}$ ' is the average inter-item correlation among the items). Responses were separately entered and used to calculate Cronbach's Alpha by using the SPSS statistical analysis software version 16.

\section{Data collection}

The field survey was conducted in the selected Tea Extension Officer ranges from October 2017 to January 2018 (4-month period) to collect data. Thirty minutes were given for each respondent for answering the knowledge measuring questionnaire. In measuring attitudes, each statement in the 
attitude questionnaire was separately explained and the respondents were allowed to express their own views and ideas for each statement freely and independently.

\section{Data processing and analysis}

Questionnaires were re-evaluated and data were entered to an Excel Worksheet (MS Excel 2010) for analysis. Respondent's attitudes were measured by summing up the score of each statement in the questionnaire (Likert, 1932; Wilcox et al., 1992). The sum of attitude score was tested for normality using the SPSS (Shapiro-Wilk test). The respondents were separated into three (03) attitude categories viz. most favourable, favourable and least favourable attitudes based on their total score by using the mean (X) and standard deviation (SD) as the measures of check using formulas adopted by Saravanan et al. (1999) (Table 01). Statement-wise attitudes were evaluated by using descriptive statistical methods. Linear relationship between independent and dependent variables was checked by using Stepwise Multiple Regression whereas the correlations were analysed by using the nonparametric statistical techniques such as Wilcoxon Rank Sum Test and Spearmen Rank Correlation method run in SPSS 16 software package.

Table 1: Formulas used to categorize the attitudes of respondents.

\begin{tabular}{ll}
\hline Attitude Category & Attitude Score \\
\hline Least favourable & $<\mathrm{X}-1 / 2 \mathrm{SD}$ \\
Favourable & $\mathrm{X}+-1 / 2 \mathrm{SD}$ \\
Most favourable & $>\mathrm{X}+1 / 2 \mathrm{SD}$ \\
\hline
\end{tabular}

\section{RESULTS AND DISCUSSION}

\section{Demographic and socio economic characteristics of respondents}

Male tea smallholders accounted for $59 \%$ of the sample while $41 \%$ were female farmers. A
$44.5 \%$ of the respondents were full time farmers whose main source of income was tea. The other $55.5 \%$ was found to be part time tea growers where the tea was a supplementary source of income for them. The smallholders were found to be between the ages 30 to 70 years. Of them, $36 \%$ of smallholders were below 40 years of age which could be considered as the younger generation involving in the sector. Meanwhile, 39\% of smallholders have been involved in tea cultivation for more than 15 years, whereas another $35.5 \%$ had $10-15$ years of experience in tea cultivation. Considering the land extent, majority (52\%) of the respondents owned $0.6-1.0$ ha, while $38 \%$ owned land extent less than 0.5 ha. The average yield of respondents was in the range of $875-1000 \mathrm{~kg} / \mathrm{ha} / \mathrm{month}$ (i.e. $350-400 \mathrm{~kg}$ /acre/month), which was significantly below the potential level.

\section{Consistency test of questionnaire}

Reliability coefficients (Cronbach $\alpha$ values) for the two questionnaires were 0.704 and 0.72 for knowledge and attitude measuring questionnaires respectively. According to Santos (1999), the consistency of a questionnaire could be accepted if the Cronbach $\alpha$ value exists at 0.7 or above. Therefore, the reliability of both the questionnaires was observed to be within the acceptable range.

\section{Attitudes on recommended agricultural practices in tea cultivation}

The Figure 1 shows the probability distribution of sum of scores of attitude statements. Horizontal axis presents sum of scores while vertical axis presents frequency. The sum of scores was normally distributed (Shapiro - Wilk test - sig 0.5) with a mean of 50.12 and standard deviation of 7.11. As the distribution was normal, the mean and the standard deviation were used to determine the attitude categories of respondents i.e. least favourable, favourable and most favourable attitudes on recommended agricultural practices. 


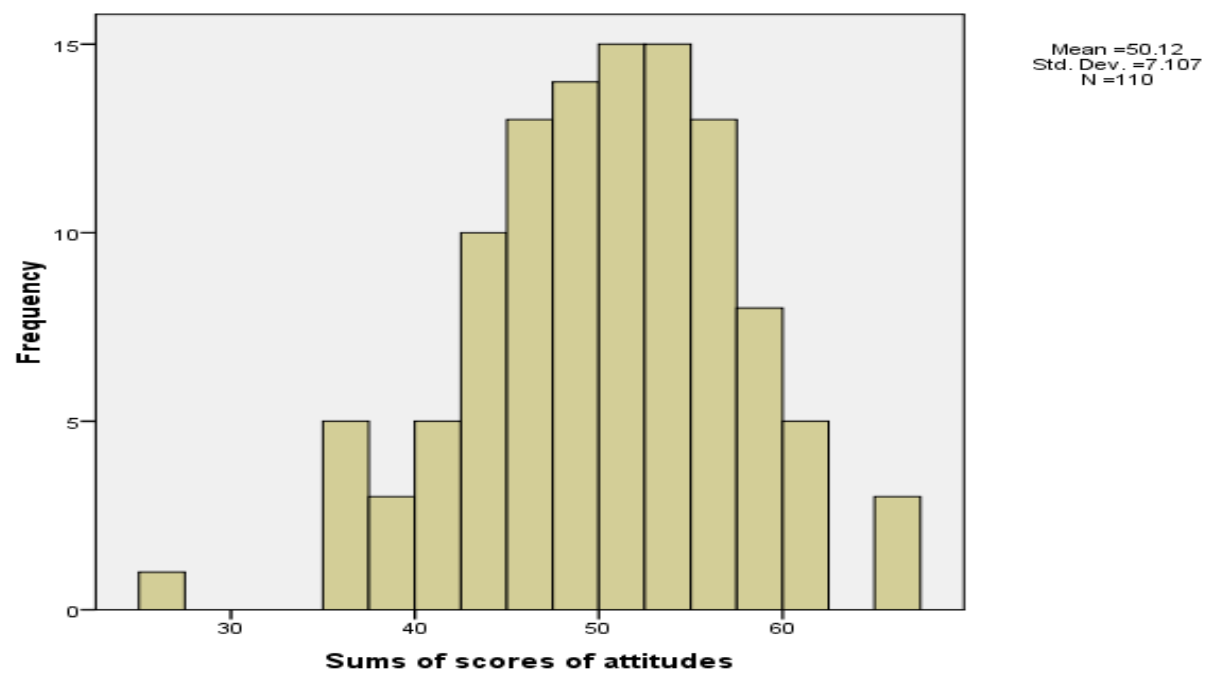

Figure 1: Probability distribution curve of attitudes.

Table 2 and Figure 2 explain the category of attitudes of respondents on recommended agricultural measures. Nearly $31 \%$ of the farmers had most favourable attitudes and another $42 \%$ had favourable attitudes. The rest $27 \%$ showed least favourable attitudes on recommended agricultural practices in tea. Overall attitudes of tea smallholders on the recommended agricultural practices in tea showed a positive trend.

Table 2: Distribution of respondents by attitude categories.

\begin{tabular}{lcccc}
\hline \multicolumn{1}{c}{ Category } & Attitude Score & Respondents (N) & Mean Score & SD \\
\hline Most favourable & $>53.68$ & 34 & 57.82 & 3.43 \\
Favourable & $46.56-53.68$ & 46 & 50.06 & 2.19 \\
Least favourable & $<46.56$ & 30 & 41.40 & 4.54 \\
\hline
\end{tabular}

\section{Analysis of statement-wise attitudes}

Majority of smallholders had negative attitudes over the extension service rendered by the government institutes while being positive towards that of private companies. Economic viability in the sense, many smallholders had no clear view regarding the impact of recommended agricultural practices on the economic life span of tea. However, majority of smallholders demonstrated positive attitudes over the importance of recommended agricultural practices for improving the productivity of tea lands such as weed management, soil fertility improvement, standard plucking and planting with newly recommended cultivars (TRI 3000 and 4000 series). Simultaneously, it was noted that smallholders preferred to implement the recommended agricultural practices which lead to a short term yield hike, rather than to practices leading to 
productivity improvements in the long run. For example, respondents had negative attitudes on soil rehabilitation which is a long term soil improvement practice in tea. However, smallholders expressed positive attitude towards progressing with tea cultivation without shifting to other crops. In general, smallholders were highly dissatisfied over the critical issues of tea industry such as cost of production, labour scarcity and the insufficient extension service.

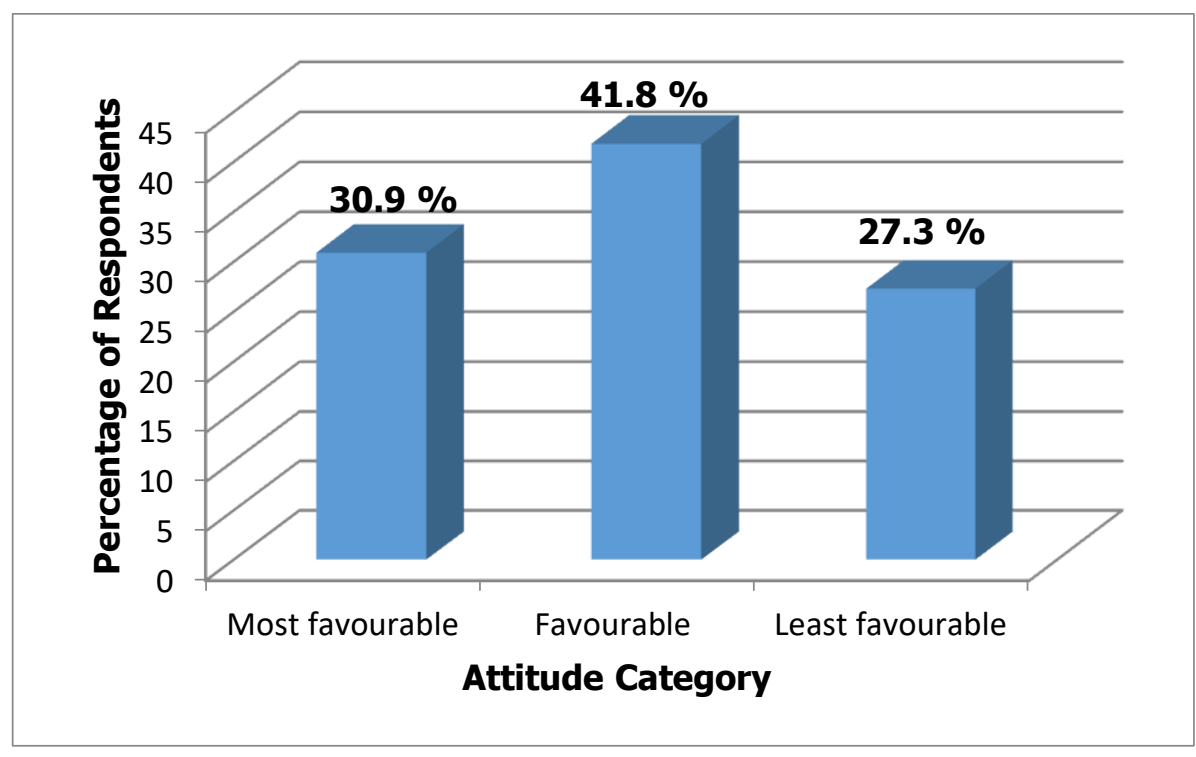

Figure 2: Distribution of respondents by attitudes.

\section{Factors affecting the attitudes of respondents}

Eight (08) demographic and socio-economic characteristics of respondents were used as independent variables. These variables were the age of smallholders, education level, knowledge, farming experience, gender, level of involvement (i.e. whether full time or part time), land extent, productivity and the exposure to extension programs. Considering these factors, stepwise multiple regression analysis was performed to elucidate the relationship between the dependent variable (i.e. attitudes) and independent variables. Among the variables examined, farmer knowledge and experience showed a significant ${ }_{2}$ linear relationship with attitudes (Table 4). Gunaratne Bandara and Sivayoganathan (1996) also reported similar findings regarding attitudes of rice farmers towards IPM practices. However, the linear relationship was not stronger since only 15 percent of the variability in the change of attitudes was explained by the two variables together i.e. knowledge and experience $\left(\mathrm{R}^{2}=\right.$ 14.8). It could therefore be assumed that other variables which were not examined may be important in explaining the variability in attitudes. 
Table 3: Statement-wise attitudes of respondents.

\begin{tabular}{|c|c|c|c|c|c|c|c|}
\hline \multirow{3}{*}{$\begin{array}{l}\text { Statement } \\
\text { No }\end{array}$} & \multirow{3}{*}{ Statement } & \multicolumn{6}{|c|}{ Response (N) } \\
\hline & & \multicolumn{2}{|c|}{ Agree } & \multicolumn{2}{|c|}{ Neutral } & \multicolumn{2}{|c|}{ Disagree } \\
\hline & & $\mathbf{N}$ & $\%$ & $\mathbf{N}$ & $\%$ & $\mathbf{N}$ & $\%$ \\
\hline 1 & Cost of cultivation is bearable & 51 & 47.2 & 1 & 0.9 & 56 & 51.9 \\
\hline 2 & Skilled pruners are rarely available & 107 & 99.1 & 0 & 0 & 01 & 0.9 \\
\hline 3 & $\begin{array}{l}\text { Mechanization is not suitable for } \\
\text { smallholders }\end{array}$ & 53 & 49.1 & 33 & 30.6 & 22 & 20.4 \\
\hline 4 & $\begin{array}{l}\text { Economic value of tea is gradually } \\
\text { diminishing }\end{array}$ & 42 & 38.9 & 60 & 55.6 & 06 & 05.6 \\
\hline 5 & $\begin{array}{l}\text { Recommendations should aim at quick } \\
\text { results }\end{array}$ & 55 & 50.9 & 08 & 7.4 & 45 & 41.7 \\
\hline 6 & $\begin{array}{l}\text { COP can be compensated by monthly } \\
\text { income }\end{array}$ & 69 & 63.9 & 29 & 26.9 & 10 & 9.3 \\
\hline 7 & $\begin{array}{l}\text { Fertilizer application: only way to increase } \\
\text { yield }\end{array}$ & 52 & 48.1 & 03 & 2.8 & 53 & 49.1 \\
\hline 8 & $\begin{array}{l}\text { Weed management without weedicide is } \\
\text { possible }\end{array}$ & 70 & 64.8 & 17 & 15.7 & 21 & 19.4 \\
\hline 9 & $\begin{array}{l}\text { Plucking round of } 7 \text { days need to be } \\
\text { changed }\end{array}$ & 40 & 37.0 & 01 & 0.9 & 67 & 62.0 \\
\hline 10 & $\begin{array}{l}\text { Productivity goes down15 - } 20 \text { years of } \\
\text { planting }\end{array}$ & 51 & 47.2 & 52 & 48.1 & 05 & 04.6 \\
\hline 11 & $\begin{array}{l}\text { Extension service rendered by } \\
\text { government institutes is adequate }\end{array}$ & 05 & 4.6 & 05 & 4.6 & 98 & 90.8 \\
\hline 12 & $\begin{array}{l}\text { Extension service rendered by private } \\
\text { companies is effective }\end{array}$ & 61 & 56.5 & 07 & 6.5 & 40 & 37.0 \\
\hline 13 & $\begin{array}{l}\text { Planting TRI new cultivars minimizes } \\
\text { bush debilitation }\end{array}$ & 56 & 50.9 & 32 & 29.1 & 22 & 20.0 \\
\hline 14 & $\begin{array}{l}\text { Soil rehabilitation prior to planting is not } \\
\text { necessary }\end{array}$ & 38 & 34.5 & 19 & 17.3 & 53 & 48.2 \\
\hline 15 & $\begin{array}{l}\text { Shifting to other crops is more } \\
\text { economically viable }\end{array}$ & 23 & 20.9 & 09 & 8.2 & 78 & 70.9 \\
\hline
\end{tabular}

Table 4: Stepwise regression on change of attitudes.

\begin{tabular}{cccc}
\hline Variables & $\mathbf{R}^{2}$ & $\mathbf{R}^{2}$ Change & P - Value \\
\hline Knowledge & 0.110 & 0.110 & 0.000 \\
Knowledge + Experience & 0.148 & 0.038 & 0.031
\end{tabular}

The correlation between the same independent variables and the dependent variable was tested with non-parametric analytical methods. As per the results, farmer knowledge, experience and level of exposure to extension programs were significantly correlated with the attitudes of tea smallholders (Table 05). Farmer knowledge was found positively correlated with attitudes whereas the farmer experience negatively correlated with attitudes. In contrast, Islam et al. (2015) 
reported positive relationship between farming experience and farmer attitude towards climate change effect on agriculture. However, as per the analytical results of this study, it was observed that with higher experiences in tea, more tendencies were there towards forming negative attitudes among smallholders.

Table 5: Factors affecting farmer attitudes.
Simultaneously, smallholders who had exposed to more extension programs per year had better attitudes on recommended agricultural practices. Gunaratne Bandara and Sivayoganathan (1996) also reported that extension contacts positively correlated with attitudes of rice farmers towards IPM practices.

\begin{tabular}{lc}
\hline \multicolumn{1}{c}{ Factor } & Significance on Attitudes \\
\hline Farmer age (years) & $\mathrm{P}-0.667$ \\
Gender & $\mathrm{P}-0.179$ \\
Farmer knowledge & $\mathrm{P}-0.002^{*}$ \\
Type of involvement & $\mathrm{P}-0.22$ \\
Farming experience (years) & $\mathrm{P}-0.01^{*}$ \\
& (correlation coefficient $(-) 0.5)$ \\
Exposure to training programs per year & $\mathrm{P}-0.001^{*}$ \\
& (correlation coefficient +0.4$)$ \\
Land extent (ha) & $\mathrm{P}-0.529$ \\
Productivity (Kg/ha/month) & $\mathrm{P}-0.736$ \\
\hline
\end{tabular}

\section{CONCLUSIONS}

The attitudes of smallholders towards implementation of recommended agricultural practices remained at a moderate level. However, negative attitudes were also found over some of the recommendations aimed at long term benefits in tea such as soil rehabilitation. It is therefore recommended giving the priority for enhancing tea smallholder attitudes regarding the importance of practicing TRI recommendations aimed at long term sustainability in tea lands. Simultaneously, it is recommended launching a program to encourage

\section{REFERENCES}

Central Bank (2017). Annual Report 2017. Central Bank of Sri Lanka. Colombo 01.

Gunaratna Bandara and Sivayoganathan, C. (1996). Factors Associated with Knowledge, Attitude and Adoption of experienced tea smallholders to participate in extension related activities. It is suggested to utilize modern technological equipment such as ICT tools (e.g. mobile phones) in extension activities aimed at capacity building of adult smallholders. The extension service of tea industry needs to be focused more on building up positive attitudes among tea smallholders rather than aiming only on knowledge improvement. The extension sector should further be equipped with related subject disciplines such as psychology etc., in order to understand the mind set of Sri Lankan tea smallholders through a proper psychoanalytical process.

Integrated Pest Management Practices in Rice Cultivation. Tropical Agricultural Research. 08, 47 - 54.

Hogg, M. and Vaughan, G. (2005). Social Psychology (4th edition). PrenticeHall, London.

Kathuri, J.N and Pals, D.A (1993). Introduction to Education Research. Educational 
Media Centre. Njoro: Egerton University

Islam, R., Biswas, J S., Akanda, G R., Hasan, I M., Al- Asif, A., Sheheli, S. and Sharif, B M. N. (2015). Attitude of the farmers towards climate change effect on agriculture. Asian Journal of Medical and Biological Research. 2015. 367379. (Online). Available at www.researchgate.net/publication/2 83664626

Kulshreshtha, S N. and Brown, W J. (1993). Role of farmers' attitudes in adoption of irrigation in Saskatchewan Irrigation and Drainage Systems. Pp. 85-98. Kluwer Academic Publishers, Netherlands.

Likert, R. (1932). A technique for the measurement of attitudes. Archives of Psychology. 140, 44-53.

Mahaliyanaarachchi, R.P. and Sivayoganathan, C. (1996). Factors Affecting Technical Knowledge of Tea Small Holders in Sri Lanka. Tropical Agricultural Research, 8, 38-46.

Mahaliyanarachchi, R.P., Wijeratna, A.W. and Bandara, R.M.A.S. (2006). Developing an Attitudinal Scale to Measure the Attitudes of the Farmers towards Commercialization of Agricultural Extension. The journal of Agricultural Sciences, 2 (3), 26 - 35.

Malkanthi, S.H.P. and Mahaliyanarachchi, R.P. (2001). Attitudes of the Farmers and Agricultural Officers on Privatization of Agricultural Extension Service in Up Country Vegetable Sector in Sri Lanka. Tropical Agricultural Research, 13, 319-327.

Meijer, S., Catacutan, D., Ajayia, O.C., Sileshi, G.W. and Nieuwenhuis, M. (2015). The role of knowledge, attitudes and perceptions in the uptake of agricultural and agro forestry innovations among smallholder farmers in sub-Saharan Africa.
International Journal of Agricultural Sustainability, $13(1), \quad 40 \quad-54$. Available at https://www.tandfonline.com/doi/fu ll

Menozzi, D., Fioravanzi, M. and Donati, M. (2015). Farmer's Motivation to Adapt Sustainable Agricultural Practices. Bio based and Applied Economics, 4(2), 125-147. Available at https://www.researchgate.net/public ation/282133518

Ministry of Plantation Industries (2013). Tea Sector. In Plantation Statistical Pocket Book for the Year 2012. Ministry of Plantation Industries. Colombo. 4-6.

O'Shea, R., O'Donoghue, C., Ryan, M. and Breen, J. (2018). Understanding farmers: From adoption to attitudes. National University of Ireland, Galway.

Rajasinghe, J.C.K. (1999). Is This the Tip of an Iceberg - A cautionary note for lowcountry tea growers. TRI Updates, Tea Research Institute of Sri Lanka, Talawakelle. 4.

Samaraweera. G.C., Ping, Q. and Yanjun, L. (2013). Promoting tea business in the tea smallholding sector in developing countries through efficient technology transfer system: Special reference to Sri Lanka. (Online). Available at http://www.academicjournals.org/AJ BM.

Santos, A.R. (1999). Cronbach's Alpha: A Tool for Assessing the Reliability of Scales. Journal of Extension. 37(2). Available at

https://www.joe.org/joe/1999april/t t3.php

Saravanan, R. and Gowda, N.S. (1999). Development of a scale to measure attitude towards privatization of agricultural extension service. Tropical Agricultural Research, 11, 190-198. 
Shikuku, K.M., Winowiecki, L., Twyman, J., Eitzinger, A., Perez, J G., Mwongera, C. and Läderach, P. (2017). Smallholding farmer attitudes and determinants of adaptation to climate risks in East Africa. Climate Risk Management. 16, 234 - 245. Available at www.sciencedirect.com

Spector, P.E. (1992). Summated rating scale construction. An introduction. Sage Publication, Newburry Park.

Tea Small Holdings Development Authority (2016). Annual Report 2016. Tea Small Holdings Development Authority, Pelawatta, Battaramulla, Sri Lanka

Tea Small Holding Development Authority (2012). Annual Report 2012. Tea
Small Holdings Development Authority, Pelawatta, Battaramulla, Sri Lanka.

Willock, J., Deary, I.J., Edwards-Jones, J., Gibson, G.J., McGregor, M.J., Sutherland, A., Dent, J.B., Morgan, O. and Grieve, R. (1999). The role of attitude and objectives in farmer decision making: Business and environmentally-oriented behaviour in Scotland. Journal of Agricultural Economics. 50(2), 286-303.

Yapa, K.D.A.J. and Ariyawardana, A. (2005). Willingness to Pay for a Fee-Based Extension Service by Tea Smallholders in Galle District, Sri Lankan Journal of Agricultural Economics, 7, 68-84. 